\title{
Editorial
}

\section{Geoffrey Burnstock}

Published online: 13 April 2011

(C) Springer Science+Business Media B.V. 2011

I asked Suso Pintor about 12 years ago to come up with an explanation about why lens cells in the eye contain such high levels of adenosine 5'-triphosphate (ATP). He has at last come up with a hypothesis which I think is worth sharing with you in the following commentary.

The lens is particularly vulnerable to volume change and swelling (which probably results in the release of ATP), which causes opacification and cataract. Furthermore, an increase in intraocular pressure releases ATP into the anterior chamber of the eye, and it was suggested that the elevated ATP may contribute to the extreme pain experienced by patients with both closed- and open-angle glaucoma [1,2]. Levels of ATP are decreased significantly in the lenses of the UPL rat, a cataract model, and it was suggested that the ATP decrease is associated with cataract development [3]. The embryonic lens has been shown to promote eye development and plays a central role in cave fish eye degeneration [4]. Perhaps released ATP is involved? Both $\mathrm{P} 2 \mathrm{X}$ and $\mathrm{P} 2 \mathrm{Y}$ receptor subtypes have been shown to be expressed on lens cells. $\mathrm{P}_{2} \mathrm{Y}_{1}$ and $\mathrm{P} 2 \mathrm{Y}_{2}$ receptor mRNA was shown to be expressed on cortex fibre cells [5] and later also $\mathrm{P}_{2} \mathrm{Y}_{4}$ and $\mathrm{P}_{2} \mathrm{Y}_{6}$ receptor subtypes were identified on epithelial cells and peripheral fibre cells of the rat lens [6-8]. RT-PCR and Western blot analyses showed mRNA and protein for P2X1-7 receptors in the lens. Immunohistochemistry showed P2X1 and P2X7 receptor expression predominately in the cytoplasm of cortical fibre cells. P2X2 receptor expression was confined

\footnotetext{
G. Burnstock $(\bowtie)$

Autonomic Neuroscience Centre, Royal Free Campus,

University College Medical School,

Rowland Hill Street,

London NW3 2PF, UK

e-mail: g.burnstock@ucl.ac.uk
}

to the apical-apical interface between epithelial and fibre cells. P2X3, P2X4. P2X5 and P2X6 receptors were expressed throughout the lens from the outer cortex through to the core and were membrane located [9]. It was speculated that the differential expression of $\mathrm{P} 2 \mathrm{X}$ receptors on the ocular lens is involved in the maintenance of lens homeostasis. It has been shown that there is $\mathrm{P} 2$ receptormediated inhibition of connexin-43, a gap junction protein, which mediates cell communication between lens epithelial cells and this suggests that this mechanism of regulating connexin-43 may play a role in maintaining the microcirculation that is essential for the movement of water and solutes in the intact lens [10]. The presence of $\mathrm{P} 2$ receptors, which, when occupied, increases $\left[\mathrm{Ca}^{2+}\right]_{\mathrm{i}}$ leading to modulation of growth of lens cells [11], perhaps representing a feedback mechanism for ATP release.

\section{References}

1. Zhang X, Li A, Ge J, Reigada D, Laties AM, Mitchell CH (2007) Acute increase of intraocular pressure releases ATP into the anterior chamber. Exp Eye Res 85:637-643

2. Castany M, Jordi I, Catala J, Gual A, Morales M, Gasull X, Pintor J (2011) Glaucoma patients present increased levels of diadenosine tetraphosphate, $\mathrm{Ap}_{4} \mathrm{~A}$, in the aqueous humour. Exp Eye Res 92:221-226

3. Nabekura T, Tomohiro M, Ito Y, Kitagawa S (2004) Changes in plasma membrane $\mathrm{Ca}^{2+}$-ATPase expression and ATP content in lenses of hereditary cataract UPL rats. Toxicology 197:177-183

4. Yamamoto Y, Jeffery WR (2000) Central role for the lens in cave fish eye degeneration. Science 289:631-633

5. Merriman-Smith R, Tunstall M, Kistler J, Donaldson P, Housley G, Eckert R (1998) Expression profiles of P2-receptor isoforms $\mathrm{P} 2 \mathrm{Y}_{1}$ and $\mathrm{P}_{2} \mathrm{Y}_{2}$ in the rat lens. Invest Ophthalmol Vis Sci 39:2791-2796

6. Donaldson PJ, Grey AC, Merriman-Smith BR, Sisley AM, Soeller C, Cannell MB, Jacobs MD (2004) Functional imaging: new 
views on lens structure and function. Clin Exp Pharmacol Physiol 31:890-895

7. Pintor J, Sanchez-Nogueiro J, Irazu M, Mediero A, Pelaez T, Peral A (2004) Immunolocalisation of $\mathrm{P} 2 \mathrm{Y}$ receptors in the rat eye. Purinergic Signal 1:83-90

8. Hu RG, Suzuki-Kerr H, Webb KF, Rhodes JD, Collison DJ, Duncan G, Donaldson PJ (2008) Molecular and functional mapping of regional differences in $\mathrm{P} 2 \mathrm{Y}$ receptor expression in the rat lens. Exp Eye Res 87:137-146
9. Suzuki-Kerr H, Vlajkovic S, Donaldson PJ, Lim J (2008) Molecular identification and localization of P2X receptors in the rat lens. Exp Eye Res 86:844-855

10. Lurtz MM, Louis CF (2007) Purinergic receptor-mediated regulation of lens connexin43. Invest Ophthalmol Vis Sci 48:4177-4186

11. Duncan G, Riach RA, Williams MR, Webb SF, Dawson AP, Reddan JR (1996) Calcium mobilisation modulates growth of lens cells. Cell Calcium 19:83-89 